DOI: https://doi.org/10.47405/mjssh.v5i4.393

\begin{tabular}{|c|c|}
\hline sin & Malaysian Journal of Social Sciences and Humanities (MJSSH) \\
\hline Malaysian Journal of & Volume 5, Issue 4, April 2020 \\
\hline (MJ-SSH) & e-ISSN : 2504-8562 \\
\hline & $\begin{array}{l}\text { Journal home page: } \\
\text { www.msocialsciences.com }\end{array}$ \\
\hline
\end{tabular}

\title{
Pembelajaran Koperatif Kemahiran 4K dan Penggunaan Media Digital Terhadap Sikap Akademik Pelajar
}

\author{
Mohd. Sahrul Nizam Sahidin', Muhamad Suhaimi Taat ${ }^{1}$ \\ 1Fakulti Psikologi dan Pendidikan, Universiti Malaysia Sabah (UMS) \\ Correspondence: Mohd. Sahrul Nizam Sahidin (sahrulsyy@gmail.com)
}

\begin{abstract}
Abstrak
Kajian ini dijalankan untuk mengenal pasti pengaruh pembelajaran koperatif kemahiran $4 \mathrm{k}$ (komunikasi, kolaborasi, pemikiran kritis dan kreatif) pelajar dan penggunaan media digital oleh guru terhadap sikap akademik pelajar dalam mata pelajaran sejarah. Responden terdiri daripada 400 orang pelajar tingkatan empat bagi 18 buah sekolah menengah harian di daerah Kota Kinabalu Sabah. Reka bentuk kajian ini adalah bukan eksperimen dengan menggunakan pendekatan kuantitatif melalui kaedah tinjauan. Instrumen kajian yang digunakan adalah melalui borang soal selidik dengan pengukuran skala likert. Data yang diperoleh dianalisis secara deskriptif dan inferensi dengan menggunakan perisian SPSS 25. Hasil dapatan kajian menunjukkan tahap penggunaan media digital oleh guru berada pada tahap sederhana. Selain itu, tidak terdapat perbezaan yang signifikan penggunaan media digital oleh guru antara pelajar lelaki dan perempuan. Terdapat juga hubungan yang signifikan tetapi lemah antara penggunaan media digital oleh guru dengan sikap akademik pelajar. Implikasi dan cadangan lanjut turut dibincangkan.
\end{abstract}

Kata kunci: pembelajaran koperatif, kemahiran 4K, media digital, sikap akademik, sejarah

\section{Cooperative Learning of 4C Skills and the Use of Digital Media Towards Students' Academic Attitudes}

\begin{abstract}
This study was conducted to identify the influence of cooperative learning of students $4 \mathrm{c}$ skills (communication, collaboration, critical and creative thinking) and the use of digital media by teachers towards students' academic attitudes in History subjects. The respondents consisted of 400 Form 4 students of 18 daily secondary schools in the Kota Kinabalu district. The design of this study is a nonexperiment that used a quantitative approach through survey method. The instrument used for this study is through questionnaires with Likert scale measurement. The data obtained is analyzed in descriptive and inferential using SPSS 25 software. The results of the findings shown that the use of digital media by teachers was at a moderate level. Meanwhile, there was no significant difference in the use of digital media by teachers between male and female students. However, there was a weak significant relationship between the use of digital media by teachers with students' academic attitudes. Further implications and suggestions were discussed.
\end{abstract}

Keywords: cooperative learning, 4K skills, digital media, academic attitutdes, history 


\section{Pengenalan}

Pengenalan sistem pendidikan Malaysia baru melalui Pelan Pembangunan Pendidikan Malaysia 20132025 (PPPM 2013-2025) terus menuju ke arah matlamat memperbaiki dan meningkatkan kualiti pendidikan negara. PPPM 2013-2025 yang mula dilaksanakan pada tahun 2013 turut membawa perubahan terhadap subjek mata pelajaran sejarah. Sejarah telah dijadikan mata pelajaran teras yang wajib lulus di peringkat peperiksaan Sijil Pelajaran Malaysia (SPM) (Mohamad Fadzil dan Abdul Jaleel, 2013). Pada tahun 2017, KPM sekali lagi melakukan perubahan terhadap kurikulum pendidikan negara dengan melancarkan penggunaan kurikulum baru pada peringkat sekolah menengah iaitu Kurikulum Standard Sekolah Menengah (KSSM) menggantikan Kurikulum Bersepadu Sekolah Menengah (KBSM). Transformasi yang dilakukan adalah selaras dengan perkembangan transformasi pendidikan abad ke-21.

Keberhasilan transformasi pendidikan yang dilakukan akan dapat ditentukan oleh Pembelajaran dan Pemudahcaraan (PdPc) yang berteraskan gaya Pembelajaran Abad ke-21. Menurut Ainun, Zamri dan Wan Muna (2017), proses PdPc yang bermakna sangat membantu dalam meningkatkan minat serta motivasi pelajar. Sikap pelajar turut membantu untuk mendorong diri mereka bagi menguasai kemahiran abad ke-21 dengan lebih cepat dan mudah (Ainun, Zamri dan Wan Muna, 2017). North Regional Educational Laboratory (NREL) dan Metri Group telah memperkenalkan model pembelajaran berteraskan abad ke-21 yang mengutarakan empat kriteria kemahiran abad ke-21. Antara kriteria tersebut ialah literasi era digital, pemikiran inventif, komunikasi berkesan dan penghasilan produktiviti tinggi (Nurul, Zamri, Nik Norhamizah, Noor dan Mohd Shah, 2012). Menurut Roekel (2017), pelajar juga perlu dilengkapi dengan kemahiran komunikasi, kolaborasi, pemikiran kritis dan kreatif (Kemahiran 4k) dalam abad ke-21.

Terdapat dua pendekatan utama yang dilaksanakan dalam PAK21 iaitu pendekatan berpusatkan pelajar dan bahan. Menurut Wright (2011), pendekatan pembelajaran berpusatkan pelajar lebih diminati dan digemari oleh pelajar. Pendekatan berpusatkan pelajar juga mampu memberi kesan yang positif (Lezah dan Rosy, 2018). Pembelajaran koperatif turut dapat membangunkan kebolehan kemahiran 4k pelajar. Pendekatan pembelajaran berpusatkan bahan pula adalah terdiri daripada sebarang bahan atau alat bantu mengajar. Antaranya Alan Bantu Mengajar (ABM) yang sesuai dengan keperluan PAK21 adalah teknologi seperti media digital. Menurut Tan dan Carol (2013), guru yang mengaplikasikan teknologi sebagai alat bantu mengajar dalam mata pelajaran sejarah dapat meningkatkan kefahaman, ingatan dan minat pelajar. Pembelajaran berasaskan teknologi di dalam bilik darjah akan menjadikan proses pembelajaran lebih menarik. Konklusinya, kajian ini akan meninjau PAK21 dari aspek pembelajaran koperatif kemahiran $4 \mathrm{k}$ dan penggunaan media digital terhadap sikap akademik pelajar.

\section{Pernyataan Masalah}

Sikap akademik pelajar dalam mata pelajaran sejarah merupakan antara masalah utama yang menyumbang kepada isu mata pelajaran sejarah. Bagi membincangkan masalah sikap ini dengan lebih jelas dan spesifik, penyelidik telah membahagikan sikap pelajar kepada tiga komponen iaitu kognitif, afektif dan perilaku. Sikap trikomponen adalah merujuk kepada tiga komponen sikap iaitu kognitif, afektif dan perilaku (Schiffman dan Kanuk, 2010). Masalah sikap kognitif pelajar yang utama adalah mengenai persepsi negatif pelajar terhadap mata pelajaran sejarah. Pelajar menganggap mata pelajaran sejarah sebagai subjek yang membosankan (Norakma, Abdul dan Noria, 2015; Siti dan Abdul, 2015; S. Azman, Mohd, Abdul, Mohd Isa dan Noor, 2017).

Masalah sikap afektif pelajar terhadap mata pelajaran sejarah pula dapat dikenal pasti dari pelbagai aspek melibatkan perasaan negatif. Pelajar merasakan bahawa mata pelajaran sejarah tidak menarik, kurang diminati dan menjemukan. Menurut Mohd. Samsudin dan Shahizan (2012), subjek sejarah tidak menarik kerana mengkaji ilmu dan peristiwa masa lalu. Malah subjek sejarah juga kurang diminati oleh pelajar (Siti dan Abdul, 2015). Bagi masalah sikap perilaku pelajar pula, perilaku negatif dalam kalangan pelajar terhadap mata pelajaran sejarah adalah kurang memberikan perhatian dalam proses pengajaran oleh guru sejarah. Menurut Azwani, Zahara, Sharifah dan Abdul dalam kajian Norakma, 
Abdul dan Noria (2015), kebanyakan pelajar menganggap subjek sejarah membosankan menyebabkan mereka kurang memberikan tumpuan.

Masalah lain yang penyumbang kepada berlaku isu dalam mata pelajaran sejarah turut disebabkan oleh kompetensi guru dalam melaksanakan PdPc. Majoriti guru sejarah yang mengamalkan pendekatan pengajaran menggunakan pendekatan pengajaran tradisional (Siti, 2008). Menurut Aimi (2017) guru menggunakan gaya pembelajaran tradisional kerana kurang menguasai pedagogi. Malah bukan itu sahaja, penggunaan media digital dalam mata pelajaran sejarah juga berada pada tahap minimum dalam kajian oleh Renuka dan Siti Hawa (2012). Menurut Anuar dan Nelson (2015) sumber digital sejarah video, visual, peta dan dokumen masih kurang dieksploitasi untuk proses PdPc di dalam bilik darjah.

\section{Objektif Kajian}

i. $\quad$ Mengenal pasti tahap penggunaan media digital oleh guru.

ii. Mengenal pasti perbezaan penggunaan media digital oleh guru berdasarkan jantina pelajar.

iii. Mengenal pasti hubungan antara penggunaan media digital oleh guru dengan sikap akademik pelajar.

\section{Hipotesis Kajian}

$\mathrm{Ho}^{1}$ Tidak terdapat perbezaan yang signifikan penggunaan media digital oleh guru berdasarkan jantina pelajar.

$\mathrm{Ho}^{2}$ Tidak terdapat hubungan yang signifikan antara penggunaan media digital oleh guru dengan sikap akademik pelajar.

\section{Tinjauan Literatur}

\section{Penggunaan Media Digital}

Kajian lepas mengenai penggunaan media digital adalah meliputi penggunaan Teknologi Maklumat dan Komunikasi (TMK) secara umum. Ini kerana tidak terdapat banyak kajian lepas berkaitan media digital secara khusus. Kajian oleh Renuka dan Siti (2012), mendapati kemahiran guru sejarah menggunakan sumber digital berada pada tahap sederhana. Manakala dalam kajian Siti Zaleha dan Siti Mistina (2017) mengenai tahap penggunaan TMK dalam kalangan guru matematik semasa proses PdP secara keseluruhannya berada pada tahap sederhana. Hanya satu item sahaja yang berada pada tahap tinggi iaitu guru melayari internet untuk penyediaan bahan PdP.

Kajian yang dilakukan di luar negara iaitu di Indonesia oleh Hasan (2016) tentang penggunaan media digital berada pada tahap tinggi. Dalam dapatan kajian tersebut, item bagi penggunaan media digital untuk pembelajaran merupakan item yang mempunyai tahap tertinggi diikuti oleh item kedua tertinggi iaitu penggunaan media digital menyelesaikan tugas. Dalam kajian oleh Anuar dan Nelson (2015), terdapat persamaan persepsi antara pelajar lelaki dan perempuan terhadap kemahiran penggunaan teknologi maklumat oleh guru sejarah. Malah terdapat juga hubungan antara penggunaan teknologi maklumat dengan tahap pencapaian akademik pelajar.

\section{Sikap Akademik Pelajar}

Kajian oleh Tika (2018) menunjukkan sikap akademik pelajar dan KBAT berada pada tahap tinggi. Hubungan sikap akademik pelajar dengan KBAT menunjukkan hubungan positif yang kuat. Dapatan 
kajian tersebut juga menunjukkan pengajaran guru didapati lebih mempengaruhi KBAT pelajar berbanding sikap akademik mempengaruhi KBAT pelajar dalam mata pelajaran sejarah tingkatan empat. Kajian oleh Ainun, Zamri dan Wan Muna (2017) menunjukkan tahap sikap pelajar terhadap pembelajaran Bahasa Melayu setelah diterapkan kemahiran abad ke-21 adalah berada pada tahap yang tinggi.

Seterusnya adalah kajian mengenai sikap akademik pelajar dalam bidang mata pelajaran sains. Kajian oleh Aziz dan Lin Hui (2011) menunjukkan majoriti pelajar mempunyai sikap negatif dalam mata pelajaran sains. Dapatan tersebut adalah sejajar dengan dapatan kajian oleh Simpson dan Oliver (1990) yang mendapati sikap pelajar terhadap sains telah menurun. Namun, dalam dapatan kajian Aziz dan Lin Hui (2011) tentang kepentingan mata pelajaran sains pula menunjukkan pelajar mempunyai sikap yang positif. Dalam hubungan antara sikap terhadap penguasaan konsep asas sains menunjukkan wujud hubungan yang signifikan. Dapatan kajian mendapati wujud hubungan yang signifikan antara sikap keyakinan diri dan persepsi terhadap kepentingan sains dengan penguasaan sains.

\section{Kerangka Konseptual Kajian}

Dalam kajian ini, sikap akademik pelajar ditetapkan sebagai pemboleh ubah bersandar. Manakal pemboleh ubah bebas adalah pembelajaran koperatif kemahiran $4 \mathrm{k}$ dan penggunaan media digital. Rajah 1 menunjukkan kerangka konseptual mengenai hubungan antara pemboleh ubah dalam kajian ini.

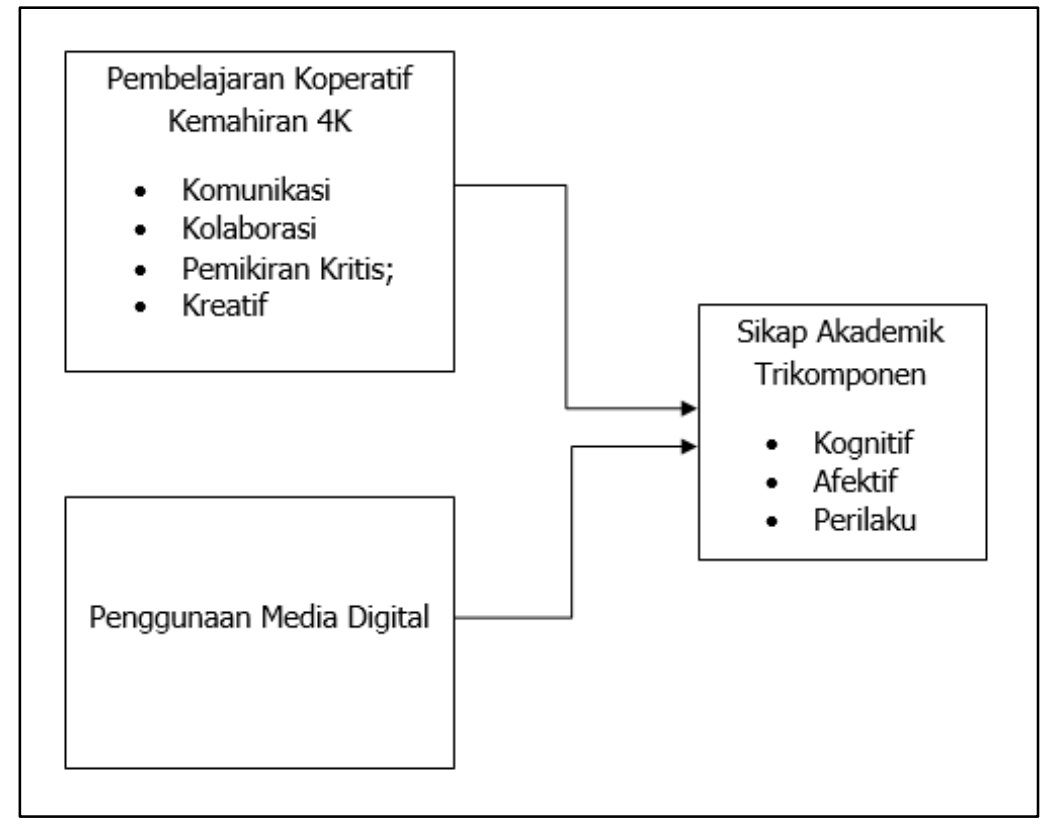

Rajah 1: Kerangka Konseptual Kajian

\section{Metod Kajian}

Kajian ini menggunakan reka bentuk kajian bukan eksperimen dengan menggunakan pendekatan kuantitatif melalui kaedah tinjauan. Menurut Mohd. Majid (2000), penyelidikan tinjauan digunakan untuk meneroka pola sesuatu fenomena yang belum dikenal pasti. Maka penyelidik menjalankan kajian ini untuk mendapatkan pola fenomena baru atau hasil kajian yang baru. Kaedah tinjauan juga dapat menghuraikan populasi yang dikaji dengan baik hasil daripada pengumpulan data sebenar (Leedy dan Ormrod, 2005).

Kajian ini dijalankan di kawasan daerah Kota Kinabalu, Sabah berdasarkan kepada Pejabat Pendidikan Daerah Kota Kinabalu (PPDKK). Terdapat 18 buah sekolah menengah harian dalam kawasan PPDKK 
yang merujuk kepada populasi kajian. Sampel yang dipilih dalam kajian ini terdiri daripada pelajar tingkatan empat sekolah menengah harian biasa. Oleh itu, penentuan saiz sampel dalam kajian ini adalah merujuk kepada jadual penentuan saiz sampel oleh Krejcie dan Morgan (1970). Jumlah keseluruhan populasi adalah sebanyak 4,330 orang pelajar maka sampel yang digunakan adalah sebanyak 400 orang seperti yang dicadangkan sekurang-kurangnya sebanyak 354 sampel menurut Krejcie dan Morgan.

Instrumen kajian ini menggunakan borang soal selidik daripada kajian lepas yang diubahsuai mengikut kesesuaian kajian dan menjalani kajian rintis untuk mendapatkan kesahan dan kebolehpercayaan. Menurut Mohd. Majid (2000), soal selidik menjadi alat ukur penyelidikan yang digunakan untuk mendapatkan maklumat yang tepat berkaitan dengan fakta, perasaan, kepercayaan dan sebagainya. Skala pengukuran yang digunakan dalam soal selidik kajian ini ialah penggunaan skala likert lima mata. Kajian ini menggunakan borang soal selidik meliputi empat bahagian iaitu bahagian A, bahagian B, Bahagian C dan Bahagian D.

Bahagian A bagi demografi responden manakala bahagian B berkaitan dengan pembelajaran koperatif kemahiran 4k dengan merujuk kepada kajian lepas oleh Eow Yee (2017) dan kajian oleh Raja Abdullah dan Daud (2018). Bahagian C merujuk kepada penggunaan media digital. Terdapat tiga kajian lepas yang dirujuk iaitu instrumen kajian daripada kajian oleh Siti Zaleha dan Siti Mistina (2017), Siti Norsyiqah dan Khairunniza (2018) dan kajian oleh Khairul, Mansor dan Mohd Mahzan (2018). Soal selidik bahagian D adalah merujuk daripada dua kajian lepas oleh Mohd Mahzan, Abdul Razaq, Nora, Sayuti, Asyraf, Mohd Asrul, Jaya Chitra, Che Pee dan Mohd Jasmy (2013) serta kajian luar negara oleh Osoro (2006).

\section{Dapatan Kajian}

\section{Tahap Penggunaan Media Digital oleh Guru}

Analisis deskriptif data frekuensi, peratusan, min dan sisihan piawai digunakan bagi menentukan tahap penggunaan media digital di dalam bilik darjah oleh guru sejarah. Pengelasan tahap yang digunakan adalah berpandukan oleh tafsiran skor min oleh Mohd Yusof (2006). Pengelasan tahap rendah, sederhana dan tinggi adalah berdasarkan purata skor min seperti jadual 2.

Jadual 2: Tafsiran Skor Min

\begin{tabular}{cc}
\hline Tahap & Purata Min \\
\hline Rendah & $1.00-2.33$ \\
Sederhana & $2.34-3.66$ \\
Tinggi & $3.67-5.00$ \\
\hline
\end{tabular}

Nilai keseluruhan tahap penggunaan media digital oleh guru sejarah di dalam bilik darjah berada pada tahap sederhana $(\mathrm{M}=3.075, \mathrm{SP}=0.873)$. Item yang mempunyai nilai min tertinggi adalah item 'Guru saya menggunakan slaid Powerpoint dalam PdP' dengan nilai $(\mathrm{M}=3.63, \mathrm{SP}=1.195)$. Walaupun item ini mendapat skor min tertinggi namun tafsiran skor min masih berada pada tahap sederhana. Item yang mempunyai nilai min terendah pula adalah item 'Guru saya menggunakan muzik dalam PdP' dengan nilai $(\mathrm{M}=2.65, \mathrm{SP}=1.215)$ pada tahap sederhana.

Jadual 3: Skor Min Penggunaan Media Digital

\begin{tabular}{rccc}
\hline Pemboleh Ubah & N & Min & SP \\
\hline Penggunaan Media Digital & 400 & 3.075 & 0.873 \\
\hline
\end{tabular}




\section{Ho1 Tidak Terdapat Perbezaan yang Signifikan Penggunaan Media Digital oleh Guru berdasarkan Jantina Pelajar}

Analisis Ujian-t sampel bebas dinilai dengan aras signifikan $\mathrm{P}<0.05$ merujuk kepada perbezaan yang signifikan (Chua, Ferlis dan Jasmine, 2016). Berdasarkan dapatan yang diperoleh daripada analisis ujian-t sampel bebas pada jadual 4, penggunaan media digital oleh guru berdasarkan jantina pelajar lelaki dan perempuan adalah tidak signifikan, $(\mathrm{t}=0.053, \mathrm{df}=296.361, \mathrm{P}>0.05)$. Oleh itu, hipotesis nul 1 diterima. Hal ini menunjukkan bahawa tidak terdapat perbezaan penggunaan media digital oleh guru sejarah berdasarkan jantina pelajar.

Jadual 4: Perbezaan Penggunaan Media Digital

\begin{tabular}{lccccccc}
\hline $\begin{array}{c}\text { Pemboleh } \\
\text { Ubah }\end{array}$ & Jantina & N & Min & Sp & t & df & $\begin{array}{c}\text { Sig. (2- } \\
\text { tailed) }\end{array}$ \\
\hline $\begin{array}{c}\text { Pengunaan } \\
\text { media digital } \\
\text { oleh guru }\end{array}$ & Lelaki & 150 & 3.07 & .913 & & & \\
\hline *Aras signifikan $(\mathrm{P}<0.05)$ & & & & & & & 0.958 \\
\hline
\end{tabular}

\section{Ho $^{2}$ Tidak Terdapat Hubungan yang Signifikan antara Penggunaan Media Digital oleh Guru dengan Sikap Akademik Pelajar}

Analisis Korelasi Pearson ditentukan melalui aras hubungan antara pemboleh ubah merujuk kepada nilai signifikan $\mathrm{P}<0.05$. Nilai kekuatan hubungan ditafsirkan berdasarkan julat numerikal antara -1.0 hingga +1.0 (Borg dan Gall, 1983). Jadual 5 menunjukkan nilai kekuatan hubungan korelasi pearson.

Jadual 5: Nilai Kekuatan Hubungan Korelasi Pearson

\begin{tabular}{cl}
\hline Nilai Pekali ' $\mathbf{R}^{\prime}$ & \multicolumn{1}{c}{ Kekuatan Hubungan } \\
\hline$>0.91$ & Hubungan sangat kuat \\
$0.71-0.90$ & Hubungan kuat \\
$0.41-0.70$ & Hubungan sederhana kuat \\
$0.21-0.40$ & Hubungan lemah \\
$<0.20$ & Hubungan sangat lemah/boleh diabaikan \\
\hline
\end{tabular}

Berdasarkan kepada hasil analisis korelasi pada jadual 6, hubungan penggunaan media digital oleh guru dengan sikap akademik pelajar mempunyai hubungan lemah tetapi signifikan $(\mathrm{R}=0.229, \mathrm{P}<0.05)$. Keputusan korelasi yang positif antara kedua-dua pemboleh ubah adalah berkadar seiras iaitu semakin tinggi penggunaan media digital oleh guru, semakin tinggi juga sikap akademik pelajar. Hal ini menunjukkan hipoteis nul 2 ditolak.

Jadual 6: Hubungan Penggunaan Media Digital dengan Sikap Akademik Pelajar

\begin{tabular}{ccc}
\hline Pemboleh Ubah & \multicolumn{2}{c}{ Sikap akademik pelajar } \\
\hline \multirow{2}{*}{ Penggunaan media digital } & Korelasi Pearson, $\mathbf{R}$ & 0.229 \\
oleh guru & Sig. (2-tailed) & 0.000 \\
& $\mathbf{N}$ & 400 \\
\hline *Aras signifikan $(\mathrm{P}<0.05)$ & &
\end{tabular}

\section{Perbincangan Dapatan Kajian}

Tahap penggunaan media digital oleh guru berada pada tahap sederhana. Tahap penggunaan yang sederhana menunjukkan bahawa penggunaan media digital dalam kalangan guru sejarah pada masa ini 
belum dimaksimumkan. Hal ini memberi kebimbangan kerana penggunaan teknologi seharusnya digunakan secara optimum pada tahap yang tinggi. Dapatan memberi gambaran bahawa PAK21 yang turut menggalakkan penggunaan teknologi dalam pelajaran sejarah hanya pada tahap sederhana sahaja.

Guru sejarah masih lagi tidak memanfaatkan sepenuhnya penggunaan media digital di dalam bilik darjah berdasarkan hasil kajian. Sumber digital sejarah dalam bentuk video, visual, dokumen dan peta masih kurang dieksploitasi (Renuka dan Siti, 2012) begitu juga dengan penggunaan media digital dalam kajian ini. Berdasarkan dapatan kajian, penggunaan media digital slaid powerpoint adalah yang paling tinggi nilai min dan yang rendah adalah audio muzik. Menurut Mohamad Johdi dan Ariegusrini (2009), guru sepatutnya mempunyai kompetensi menggunakan teknologi dalam pengajaran keran banyak sumber sejarah yang boleh diperoleh.

Selain itu, dapatan kajian mendapati tiada perbezaan yang signifikan antara pelajar lelaki dan perempuan terhadap penggunaan media digital oleh guru. Dapatan ini kajian ini selari dengan kajian oleh Anuar dan Nelson (2015) yang mendapati persepsi antara pelajar lelaki dan perempuan adalah sama terhadap kemahiran penggunaan teknologi maklumat oleh guru sejarah. Dapatan kajian tersebut menyokong dapatan kajian ini kerana penggunaan media digital oleh guru sejarah menurut pelajar lelaki dan perempuan adalah sama. Hal ini kerana, setiap pelajar tidak mengira jantina menerima penggunaan media digital oleh guru dalam aktiviti PdPc.

Antara lain juga, terdapat hubungan penggunaan media digital oleh guru dengan sikap akademik pelajar. Hubungan antara kedua-dua pemboleh ubah ini mempunyai hubungan lemah. Keputusan korelasi yang positif antara kedua-dua pemboleh ubah adalah berkadar seiras iaitu semakin tinggi penggunaan media digital oleh guru, sikap akademik pelajar turut semakin tinggi. Kajian oleh Nurazidawati (2011), tentang penyepaduan kemahiran abad ke-21 dalam pengajaran biologi menunjukkan pengajaran berteraskan PAK21 iaitu meliputi teknologi mempunyai hubungan yang positif terhadap sikap pelajar. Hal ini menunjukkan dapatan kajian ini dapat disokong oleh dapatan kajian tersebut kerana terdapat hubungan antara penggunaan teknologi dengan sikap pelajar.

\section{Implikasi dan Cadangan}

Implikasi terhadap penyelidikan dapat dilihat dengan jelas dari dapatan kajian yang diperoleh. Kajian ini mendapati Tahap penggunaan teknologi seperti media digital oleh guru dalam mata pelajaran sejarah pula hanya berada pada tahap yang sederhana. PAK21 yang sering kali dikaitkan dengan teknologi telah menimbulkan kerisauan terhadap penggunaan media digital. Keadaan ini menunjukkan bahawa penggunaan media digital dalam kalangan guru sejarah yang berada pada tahap sederhana perlu dipantau. Hal ini kerana perkembangan globalisasi kini semakin pesat dan hampir kesemua orang telah menggunakan media digital terutamanya telefon. Malah teknologi juga terus berkembang maju dalam sektor pendidikan.

Implikasi kajian terhadap sikap akademik pelajar pula turut berada pada tahap sederhana tetapi sangat positif. Dapatan ini menunjukkan bahawa isu mata pelajaran sejarah yang berkait rapat dengan sikap pelajar dalam keadaan yang baik. Dapatan ini juga telah dapat menjawab isu kajian pada masa ini. Sikap akademik pelajar yang positif walaupun berada pada tahap sederhana adalah sesuatu dapatan yang baik dan baru. Perkara ini turut mempunyai kaitan pengaruh pembelajaran koperatif kemahiran 4k dan penggunaan media digital oleh guru dalam mata pelajaran sejarah.

Berdasarkan kepada jurang kajian yang wujud, maka penyelidik mencadangan untuk kajian lanjutan dilakukan. Kajian lanjutan penting bagi memenuhi sebarang jurang yang dapat dikenal pasti melalui skop kajian dan dapatan kajian. Antara cadangan kajian lanjutan yang boleh dilakukan adalah seperti kajian lanjutan antara sekolah bandar dan luar bandar untuk melihat dapatan melalui perbandingan, menambah aspek-aspek berkaitan dengan demografi lain yang boleh dikaji atau menukar reka bentuk kajian kepada pendekatan kualitatif untuk mendapatkan dapatan data yang baru. 


\section{Kesimpulan}

Kajian ini jelas menunjukkan bahawa penggunaan media digital dalam mata pelajaran sejarah masih berada pada tahap sederhana dan memerlukan tindakan lanjut bagi mengenal pasti punya perkara sedemikian terjadi. Setiap pelajar juga tidak mengira jantina sama-sama menerima proses PdPc penggunaan media digital oleh guru sejarah. Dari aspek hubungan jelas menunjukkan terdapat hubungan yang positif walaupun lemah antara penggunaan media digital dengan sikap akademik pelajar. Secara keseluruhannya, kajian ini dapat memberikan gambaran baru dan jelas terhadap PAK21 dari aspek penggunaan media digital oleh guru di dalam bilik darjah dan pengaruhnya terhadap sikap akademik pelajar dalam mata pelajaran sejarah.

\section{Rujukan}

Aimi Hafizah binti Fadzilah. (2017). Pelaksanaan Pengajaran dan Pembelajaran Koperatif Berasaskan Abad ke-21: Satu Tinjauan di Sekolah Menengah Kebangsaan Pekan Nenas. Fakulti Pendidikan Teknikal dan Vokasional, Univerisiti Tun Hussien Onn Malaysia.

Ainun Rahmah Iberahim, Zamri Mahamod dan Wan Muna Ruzanna Wan Mohammad. (2017). Pembelajaran Abad Ke-21 dan Pengaruhnya Terhadap Sikap, Motivasi dan Pencapaian Bahasa Melayu Pelajar Sekolah Menengah. Jurnal Pendidikan Bahasa Melayu. 7(2), 77-88.

Anuar Ahmad dan Nelson Jinggan. (2015). Pengaruh Kompotensi Kemahiran Guru dalam Pengajaran terhadap Pencapaian Akademik Pelajar dalam Mata Pelajaran Sejarah. JuKu: Jurnal Kurikulum \& Pengajaran Asia Pasifik. 3(2),1-11.

Aziz Nordin dan Lin Hui Ling. (2011). Hubungan Sikap Terhadap Mata Pelajaran Sains dengan Penguasaan Konsep Asas Sains Pelajar Tingkatan Dua. Journal of Science \& Mathematics Educational, 2, 89-101.

Borg, W. R. \& Gall, M. D. (1983). Educational Research and Introduction. New York:Longman.

Chua Bee Seok, Ferlis Bullare dan Jasmine Adela Mutang. (2016). SPSS: Prinsip dan Analisis dalam Sains Tingkah Laku (Edisi 5). McGraw-Hill.

Hasan Subekti. (2016). Representasi Penggunaan Media Digital dan Pembelajaran Berbasis Penelitian: Sebuah Survei untuk Mengukur Perilaku pada Mahasiswa Baru di Program Studi Pendidikan Sains Unesa. Jurusan Ilmu Pengetahuan Alam, Fakultas Matematika dan Ilmu Pengetahuan Alam, Universitas Negeri Surabaya. Jurnal Penelitian Pendidikan IPA, JPPIPA, 1(1).

Khairul Ghufran Kaspin, Mansor Mohd Noor dan Mohd Mahzan Awang. (2018). Perspektif Pelajar Terhadap Kurikulum Sejarah Peringkat Menengah di Malaysia. UPSI dan UKM.

Leedy, P. D. \& Ormrod, J. E. (2005). Practical Research Planning and Design. ( ${ }^{\text {th }}$ Ed.). $\quad$ Upper Saddle River. New York. Prentice-Hall, Inc.

Lezah@ Lejah binti Kiamsin dan Rosy Talin. (2018). Kaedah Pengajaran Sejarah yangDiminati Pelajar dan Justifikasinya. Malaysian Journal of Social Sciences and Humanities. 3(2), 137-145.

Mohamad Fadzil Che Amat dan Abdul Jaleel Abdul Hakeem (2013). Menilai Keberkesanan Pelaksanaan Program Diploma Perguruan Lepas Ijazah Pendidikan Sejarah Sekolah Rendah di Institut Pendidikan Guru Kampus Pulau Pinang. Seminar Pendidikan Sejarah dan Geografi 2013. 29-30 Ogos 2013. Hlm. 214-225.

Mohamad Johdi Bin Salleh \& Ariegusrini Bte Agus. (2009). Transformasi Pengajaran Sejarah Berasaskan Multimedia. Dlm Abdul Razaq \& Isjoni. Transformasi Pengajaran dan Pembelajaran Sejarah. Penerbitan Bersama: Fakulti Pendidikan Universiti Kebangsaan Malaysia, Bangi dan FKIP, Universitas Riau, Pekan Baru Indonesia. Hlm. 113-126.

Mohd Mahzan Awang, Abdul Razaq Ahmad, Nora Asikin Abu Bakar, Sayuti Abd Ghani, Asyraf Nadia Mohd Yunus, Mohd Asrul Hery Ibrahim, Jaya Chitra Ramalu, Che Pee Saad dan Mohd Jasmy Abd Rahman. (2013). Students' Attitudes and Their Academic Performance in Nationhood Education. International Education Studies. Canadian Center of Science and Education, 6(11).

Mohd Yusof Abdullah. (2006). Pengaruh Motif, Sikap dan Latihan Perguruan Terhadap Profesionalisme Keguruan di Kalangan Pelajar Program Pendidikan IPTA. Tesis Doktor Falsafah. Universiti Malaysia Sabah, Kota Kinabalu, Sabah. 
Mohd. Majid Konting. (2000). Kaedah Penyelidikan Pendidikan. Kuala Lumpur: Dewan Bahasa dan Pustaka.

Mohd. Samsudin dan Shahizan Shaharuddin. (2012). Pendidikan Dan Pengajaran Mata Pelajaran Sejarah Di Sekolah Di Malaysia. Jebat: Malaysian Journal of History, Politics $\quad \& \quad$ Strategy. $39(2), 116-141$.

Norakma binti Mohd Daud, Abdul Razak Ahmad dan Noria Munirah Yakub. (2015). Pembelajaran Berteraskan Kemahiran Berfikir Aras Tinggi (KBAT) di DalamPengajaran dan Pembelajaran Mata Pelajaran Sejarah. Proceeding: $7^{\text {th }}$ International Seminar on Regional Education, Nov, 5-7, 352-360.

Nurazidawati Mohamad Arsad. (2011). Penyepaduan Kemahiran-Kemahiran Abad Ke-21 dalam Pengajaran Dan Pembelajaran Biologi. (Tesis Sarjana Pendidikan) Universiti Kebangsaan Malaysia.

Nurul Ain Azmi, Zamri Mahamod, Nik Norhamizah Nek Ali, Noor Syazwani Roni dan Mohd Shah Rizal Othman. (2012). Penyepaduan Kemahiran-Kemahiran Abad Ke-21 dalam Pengajaran dan Pembelajaran Kesusasteraan Melayu. International Seminar on educational Comparative in Competency Based Curriculum Between Indonesia and Malaysia 2012.

Raja Abdullah Raja Ismail dan Daud Ismail. (2018). Aplikasi Konsep 4C Pembelajaran Abad ke-21 dalam Kalangan Guru Pelatih Pengajian Agama Institut Pendidikan Guru kampus Dato Razali Ismail. Institut Pendidikan Guru Kampus Dato Razali Ismail. Univerisiti Sultan Zainal Abidin. Asian People Journal. 1(1), 45-65.

Renuka Ramakrishnan \& Siti Hawa Abdullah. (2012). Penggunaan Sumber Digital Sejarah dalam Kalangan Guru Sejarah. Seminar Kebangsaan Majlis Dekan Pendidikan IPTA. Universiti Teknologi Malaysia.

Roekel, D. V. (2017). Preparing $21^{\text {st }}$ Century Students for a Global Society. National Education Associatuion. Washington, Dc.

S. Azman Ligun, Mohd Mahzan Awang, Abdul Razaq Ahmad, Mohd Isa Hamzah dan Noor Wahidan Hassan. (2017). Muzium Sebagai Instrumen Pembelajaran Sejarah Luar Bilik Darjah. Jurnal Kurikulum \& Pengajaran Asia Pasifik. 5(1), 19-30.

Schiffman, L. G., \& Kanuk, L. L. (2010). Consumer Behaviour (10th ed). New Jersey, Pearson Prentice Hall.

Simpson, R. D. \& Oliver, J. S. (1990). A Summary of Major Influences on Attitude Toward and Achievement in Science Among Adolescent Students. Science Education, 74(1), 1-18.

Siti Hawa Abdullah. (2008). Empati Sejarah Dalam Pengajaran dan Pembelajaran Sejarah. Jurnal Pendidik dan Pendidikan. 28(1), 131 -146.

Siti Norsyiqah Binti Azmi dan Khairunniza Binti Abdul Hamid. (2018). Penggunaan Nota Digital Meningkatkan Pencapaian Murid Dalam Mata Pelajaran Sejarah Tingkatan Satu. Proceedings of International Conference on The Future of Education 2018, Institute of Teacher Education Tuanku Bainun Campus, Penang, Malaysia, 10-12 July 2018.

Siti Zaleha Hamid dan Siti Mistina Maat. (2017). Teknologi Maklumat dan Komunikasi dalam Pengajaran dan Pembelajaran dalam Kalangan Guru Matematik di Zon Kajang, Selangor. Fakulti Pendidikan, Universiti Kebangsaan Malaysia.

Siti Zubaidah Bt Che Mohd Noor dan Abdul Razak Ahmad. (2015). Kreativiti Guru Dalam Meningkatkan Kefahaman Dan Penghayatan Sejarah. Proceeding: $7^{\text {th }}$ International Seminar on Regional Education. Nov, 5-7, 457-468.

Tan Choon Keong \& Carol Abu. (2013). Pengaplikasian Video Youtube: Bahan Bantu Mengajar (BBM) dalam Proses Pengajaran dan Pembelajaran Mata Pelajaran Sains Sosial. Universiti Malaysia Sabah.

Tika binti Ali Asmad. (2018). Pengaruh Pengajaran Guru dan Sikap Akademik Pelajar terhadap KBAT dalam Mata Pelajaran Sejarah Tingkatan Empat. Jurnal Sultan Alauddin Sulaiman Shah. Special Issue. 161-169.

Wright, G. B. (2011). Student-Centered Learning in High Education. International Journal of Teaching and Learning in Higher Education. 23(3), 101-113. 